U.S. Geological Survey National Assessment of Oil and Gas Resources Project

\title{
Map of Assessed Tight-Gas Resources in the United States, 2014
}

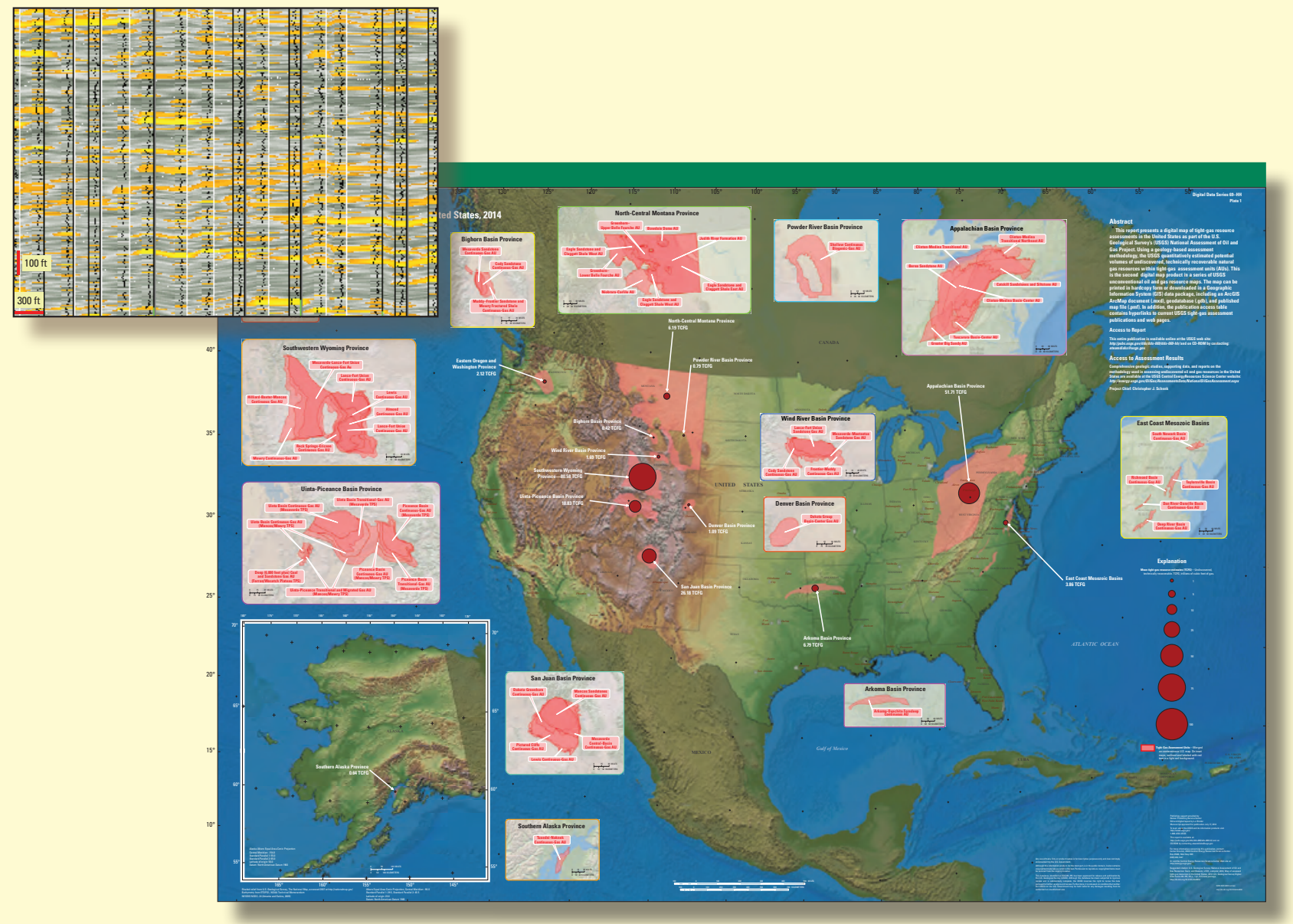

Digital Data Series DDS-69-HH 
COVER. Cross section shows lenticular fluvial sandstone reservoirs within the continuous gassaturated interval in the Williams Fork Formation of the Mesaverde Group, Piceance Basin, Colorado. Graphic by Steve Cumella, consulting geologist. Map from figure 1, this publication. 


\section{Map of Assessed Tight-Gas Resources in the United States, 2014}

By U.S. Geological Survey National Assessment of Oil and Gas Resources Team, and Laura R.H. Biewick, compiler

U.S. Geological Survey National Assessment of Oil and Gas Resources Project

Digital Data Series DDS-69-HH 


\section{U.S. Department of the Interior \\ SALLY JEWELL, Secretary}

\section{U.S. Geological Survey \\ Suzette M. Kimball, Acting Director}

\section{U.S. Geological Survey, Reston, Virginia: 2014}

For more information on the USGS — the Federal source for science about the Earth, its natural and living resources, natural hazards, and the environment, visit http://www.usgs.gov or call 1-888-ASK-USGS.

For an overview of USGS information products, including maps, imagery, and publications, visit http://www.usgs.gov/pubprod

To order this and other USGS information products, visit http://store.usgs.gov

Any use of trade, product, or firm names is for descriptive purposes only and does not imply endorsement by the U.S. Government.

Although this report is in the public domain, permission must be secured from the individual copyright owners to reproduce any copyrighted materials contained within this report.

Suggested citation:

U.S. Geological Survey National Assessment of Oil and Gas Resources Team, and Biewick, L.R.H., compiler, 2014, Map of assessed tight-gas resources in the United States, 2014: U.S. Geological Survey Digital Data Series 69-HH, 6 p., 1 pl., GIS data package, http://dx.doi.org/10.3133/ds69HH. 


\section{Contents}

Abstract
Introduction
Print Map
Web Services
Download Maps and Data
Acknowledgments
References Cited.

\section{Plate}

1. Map of assessed tight-gas resources in the United States, 2014 ................................ link

\section{Figure}

1. Map graphic links to the tight-gas resources hardcopy map...........................................

\section{Table}

1. Publication access table-Hyperlinks to USGS tight-gas assessment publications and web pages. 


\section{Conversion Factors}

Inch/Pound to SI

\begin{tabular}{ccc}
\hline Multiply & By & To obtain \\
\hline inch (in.) & Length & \\
\hline & 25.4 & millimeter $(\mathrm{mm})$ \\
\hline cubic foot $\left(\mathrm{ft}^{3}\right)$ & Volume & \\
\hline
\end{tabular}

SI to Inch/Pound

\begin{tabular}{ccc}
\hline Multiply & By & To obtain \\
\hline millimeter $(\mathrm{mm})$ & Length & \\
\hline & 0.03937 & inch (in.) \\
\hline cubic meter $\left(\mathrm{m}^{3}\right)$ & Volume & cubic foot $\left(\mathrm{ft}^{3}\right)$ \\
\hline
\end{tabular}

Temperature in degrees Celsius $\left({ }^{\circ} \mathrm{C}\right)$ may be converted to degrees Fahrenheit $\left({ }^{\circ} \mathrm{F}\right)$ as follows:

${ }^{\circ} \mathrm{F}=\left(1.8 x^{\circ} \mathrm{C}\right)+32$

Temperature in degrees Fahrenheit $\left({ }^{\circ} \mathrm{F}\right)$ may be converted to degrees Celsius $\left({ }^{\circ} \mathrm{C}\right)$ as follows:

${ }^{\circ} \mathrm{C}=\left({ }^{\circ} \mathrm{F}-32\right) / 1.8$

Permeability in millidarcies $(\mathrm{mD})$ 


\title{
Map of Assessed Tight-Gas Resources in the United States, 2014
}

\author{
By U.S. Geological Survey National Assessment of Oil and Gas Resources Team, \\ and Laura R.H. Biewick, compiler
}

\section{Abstract}

This report presents a digital map of tight-gas resource assessments in the United States as part of the U.S. Geological Survey's (USGS) National Assessment of Oil and Gas Project. Using a geology-based assessment methodology, the USGS quantitatively estimated potential volumes of undiscovered, technically recoverable natural gas resources within tight-gas assessment units (AUs). This is the second digital map product in a series of USGS unconventional oil and gas resource maps. The map plate included in this report can be printed in hardcopy form or downloaded in a Geographic Information System (GIS) data package, including an ArcGIS ArcMap document (.mxd), geodatabase (.gdb), and published map file (.pmf). In addition, the publication access table contains hyperlinks to current USGS tight-gas assessment publications and web pages.

\section{Introduction}

The U.S. Geological Survey (USGS) carries out scientific investigations and conducts assessments of geologically based energy resources, including unconventional resources (for example, shale gas, tight gas, unconventional oil, and coalbed methane). These scientific studies are used to evaluate and assess the quality and distribution of energy resource accumulations and the undiscovered, technically recoverable energy resource potential of the United States (U.S.). This publication summarizes the results of the U.S. tight-gas assessment in a geospatial map and data package.

The total petroleum system (TPS) is the basic geologic unit of the oil and gas assessment; it includes all of the essential elements and processes needed for oil and gas accumulations to exist, including the presence of source and reservoir rocks, hydrocarbon generation and migration, traps and seals, and undiscovered accumulations. An assessment unit is a mappable volume of rock within a total petroleum system in which discovered and undiscovered resource accumulations are relatively similar with respect to geology, exploration strategy, and risk characteristics (Ahlbrandt, 2000, no page numbers). Tight gas is natural gas trapped in formations with very low permeability to gas $(0.1 \mathrm{mD}$ or less $)$ due to fine grain size and poorly connected pores.

Comprehensive geologic studies, supporting data, and reports on the methodology used in assessing undiscovered oil and gas resources in the United States are available at the USGS Central Energy Resources Science Center website at: http://energy.usgs.gov/OilGas/AssessmentsData/NationalOilGasAssessment.aspx

\section{Print Map}

The map of tight-gas resources is available as a static Portable Document Format (.pdf) file and as an interactive map contained on a CD-ROM. These products are also available at $h t t p: / / p u b s . u s g s . g o v / d d s / d d s-069 / d d s-069-h h /$ or http://dx.doi.org/10.3133/ds69HH. The software used to create this digital map product includes Environmental Systems Research Institute, Inc. (Esri) ArcGIS 10, Python, Adobe Photoshop CS5.1, Illustrator CS5.1, and Acrobat 7.0.

To access the hardcopy .pdf map, click on the map graphic shown in figure 1. Adobe Acrobat Reader software is recommended to view the .pdf map and is available for download free at $h$ ttp://get.adobe.com/reader/. 


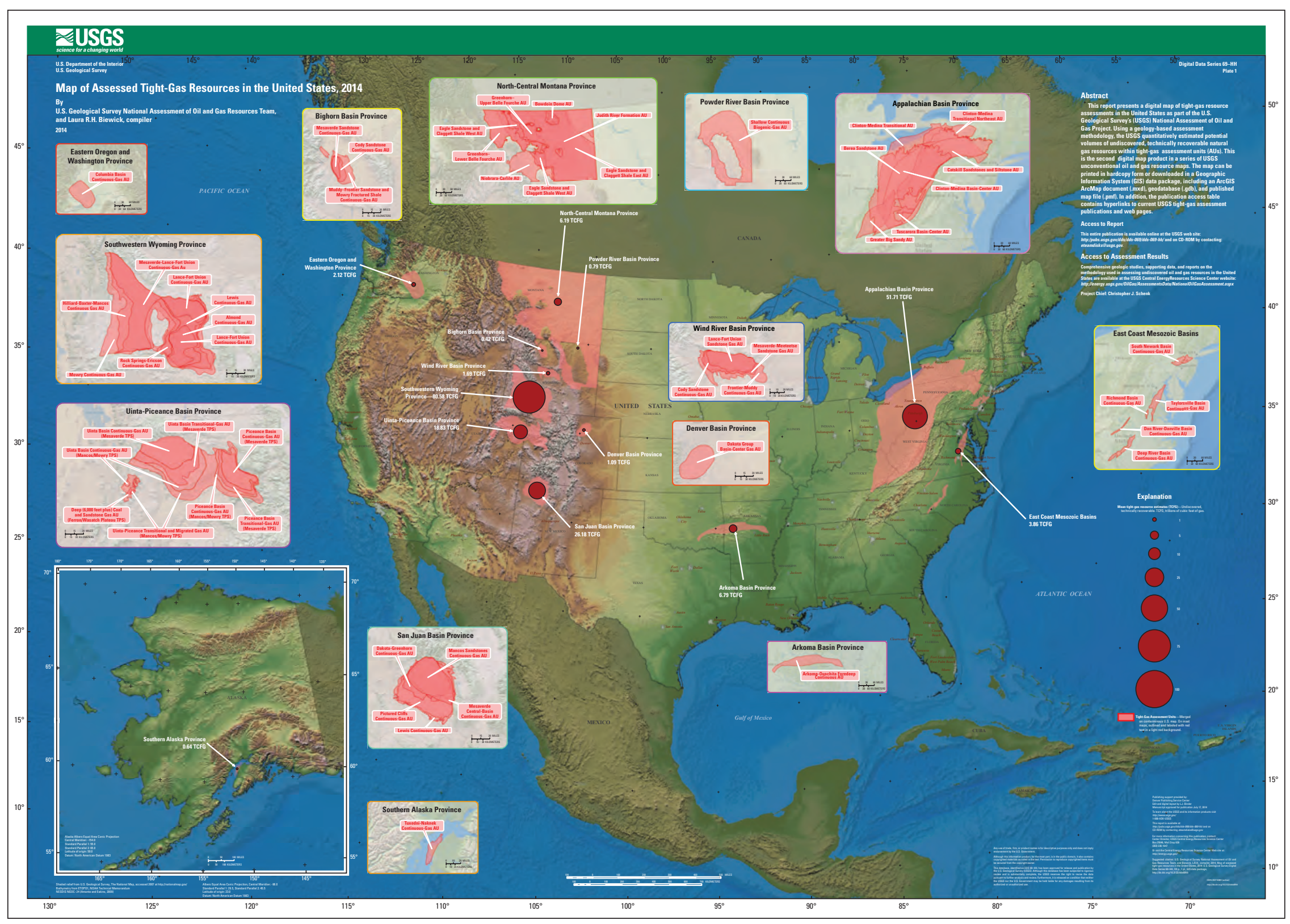

Figure 1. The hardcopy .pdf map is designed to be printed on a $45 \times 32$ inch map sheet. The map graphic links to the tight-gas resources hardcopy map. Link. 


\section{Web Services}

This report also includes a web map service. To access the tight-gas web service, visit the USGS National Assessment of Oil and Gas Resources website at http://energy.usgs.gov/ OilGas/AssessmentsData/NationalOilGasAssessment.aspx.

\section{Download Maps and Data}

The map of assessed tight-gas resources is available as a GIS map and data package that is contained on CD-ROM or can be downloaded from the USGS website at $h t t p: / /$ pubs.usgs.gov/dds/dds-069/dds-069-hh/ or http://dx.doi. org/10.3133/ds69HH. The ArcMap document, whose filename contains an .mxd extension, is the main component of the GIS data package and is used to analyze geospatial data, symbolize features, and create maps. Access to the .mxd file requires Esri's ArcGIS 10 or newer versions of the desktop software (Esri, 2000). Using the published .mxd and the ArcGIS Publisher extension (ESRI, 2008a) in ArcMap, a special file called a published map file was created. Published map files contain a .pmf extension, and can be accessed using any ArcGIS (Esri, 2000) desktop product, including the free ArcReader (Esri, 2008b) application. ArcMap and ArcReader offer different ways to view a map, in which one can perform map-based tasks. ArcReader provides basic tools for map viewing, printing and querying of geospatial data. More advanced geospatial processing requires the ArcGIS suite of geospatial processing programs, including ArcMap.

There are two ArcMap documents contained in this report: (1) TightGasMap2014.mxd, and (2) TightGasMap2014simplified.mxd. TightGasMap2014.mxd is a complex ArcGIS project used to build, design, and export the .pdf map. Multiple data frames enable the advanced user to navigate each province area; upon initial launch, this file tends to be much slower than subsequent map starts. TightGasMap2014simplified.mxd is designed for a novice GIS user to easily navigate and utilize these data.

The digital map layout of both the .mxd and the .pmf contains a map window with a series of layers in the table of contents frame on the left side of the navigation screen. Within the table of contents, select the box to the left of each layer or group of layers to display the features in map view. Click the "+" sign to the left of each layer, group, or data frame to display the symbology or the list of layers within that group or data frame. To deselect the entire group, ctrl-click the check box to the left of any one of the AU names. Ctrl-click again to toggle the check boxes on for the entire group.

By default, the map is in Layout View, and Contiguous U.S. (lower 48) is the active data frame. Layout View is designed to work with the map layout and graphic elements, such as titles, north arrows, and scale bars, along with the data frame, all of which are arranged on a page. Data View is designed for exploring, displaying, and querying the data sets presented on the map, which is displayed in real-world coordinates (Esri, 2011). Navigation between Layout View and Data View is available from the View drop-down menu.

Labels and annotation for the AUs are included as separate layers that can be toggled on and off, as deemed appropriate for a particular map display. In the simplified .mxd, the 'Tight-Gas AU Annotation' layer, when visible, shows all tight-gas AU names. Users may wish to zoom into a particular area of interest, in which case, individual province labels available within each province group can be toggled on and the AU annotation layer can be toggled off (made invisible).

ArcMap documents (.mxd) and published map files (.pmf) can be enhanced by including auxiliary base map layers, many of which are available as ArcGIS services (for example, shaded relief, world imagery; Esri, 2010). Several base layers are visible upon opening the map document, and setup as the default view. An important base layer, geologic units from the Geologic Map of North America (Reed and others, 2005; Garrity and Soller, 2009), is included for additional geologic context. Because many of these base layers are very large files, toggling these layers off can hasten map display while navigating the interactive map. Once an appropriate map graphic has been created or area of interest has been isolated the addition of one or more of the base layers can enhance the final map product or view.

All geospatial data are stored in file geodatabase (Esri, 2012; TightGas2014.gdb and BaseLayers.gdb) and shapefile format in a World Geodetic System (WGS) 1984 projection, which is a standard projection for distributing geospatial data. The polygons in TightGas2014.gdb represent the tight-gas AUs that have been defined and assessed by the USGS. An important aspect of this map product is that it does not require extensive GIS expertise or highly specialized equipment to use.

The Metadata folder contains tight-gas data documentation in XML, html, and text format. The base map layers have metadata incorporated from the published sources. Reference or base layers from "The National Atlas of the United States of America" (U.S. Department of the Interior, 2008) include state and county boundaries, streams, water bodies, and urban areas in the United States. For the ArcGIS.com web services (formerly ArcGIS Online; Esri, 2010), data descriptions, sources, and credits are stored as layer properties.

\section{Summary}

The USGS map of the principal tight-gas resources in the United States portrays the occurrence of this important resource. Estimates of the tight-gas resource, especially the portion that is technically recoverable, are likely to change over time as our geologic understanding of the resource characteristics increases, and with further advances in recovery methods. New information can be readily added to this digital baseline developed for the USGS National Assessment of Oil 
and Gas project. The ability to view, edit, create, and analyze geospatial data can enhance/increase our understanding of tight-gas resources and assessments.

\section{Acknowledgments}

This report is a compilation of work by many USGS Energy Resources Program geologists who presented the geologic evidence critical to defining and assessing tight-gas resource volumes across the United States. The manuscript was improved by reviews from Christopher J. Schenk, Jon Haacke, and Dave Ferderer, and thanks are extended to them for their thoughtful evaluations and suggested revisions.

\section{References Cited}

Ahlbrandt, T.S., 2000, Introduction, in U.S. Geological Survey world petroleum assessment 2000 - Description and results: U.S. Geological Survey Digital Data Series 60, v. 1.0, 4 CD-ROMs., http://pubs.usgs.gov/dds/dds-060/.

Amante, Christopher, and Eakins, B.W., 2009, ETOPO1 1 Arc-minute global relief model-Procedures, data sources and analysis: National Oceanic and Atmospheric Administration (NOAA) Technical Memorandum NESDIS NGDC24, 19 p., http://www.ngdc.noaa.gov/mgg/global/relief/.

Anna, L.O., Charpentier, R.R., Cook, T.A., Klett, T.R., Pollastro, R.M., and Schenk, C.J., 2006, Assessment of undiscovered oil and gas resources of the Powder River Basin Province of Wyoming and Montana-2006 update: U.S. Geological Survey Fact Sheet 2006-3135, 2 p., http://pubs. usgs.gov/fs/2006/3135/.

Anna, L.O., Klett, T.R., and Le, P.A., 2009, Total petroleum systems and geologic assessment of oil and gas resources in the Powder River Basin Province, Wyoming and Montana (rev. April 2010): U.S. Geological Survey Digital Data Series 69-U, 3 chaps., http://pubs.usgs.gov/dds/dds-069/ $d d s-069-u /$. [Also available on CD-ROM.]

Brownfield, M.E., Tennyson, M.E., Ahlbrandt, T.S., Charpentier, R.R., Cook, T.A., Klett, T.R., Pollastro, R.M., and Schenk, C.J., 2006, Assessment of undiscovered gas resources of the Eastern Oregon and Washington Province, 2006: U.S. Geological Survey Fact Sheet 2006-3091, 2 p., http://pubs.usgs.gov/fs/2006/3091/.

Environmental Systems Research Institute, Inc. (Esri), 2000, ArcGIS: Esri, Redlands, Calif., accessed January 27, 2012 at http://www.esri.com/software/arcgis/index.html.
Environmental Systems Research Institute, Inc. (Esri), 2008a, ArcPublisher: Esri, Redlands, Calif., accessed January 27, 2012 at http://www.esri.com/software/arcgis/extensions/ publisher/index.html.

Environmental Systems Research Institute, Inc. (Esri), 2008b, ArcReader: Esri, Redlands, Calif., accessed January 27, 2012 at http://www.esri.com/software/arcgis/arcreader/ download.html.

Environmental Systems Research Institute, Inc. (Esri), 2010, ArcGIS online: Esri, Redlands, Calif., accessed January 27, 2012 at http://www.esri.com/software/arcgis/arcgisonline/ index.html.

Environmental Systems Research Institute, Inc. (Esri), 2011, Displaying maps in data view and layout view, ArcGIS Desktop 10.0 Help: Esri, Redlands, Calif., accessed January 27, 2012 at http://www.esri.com/.

Environmental Systems Research Institute, Inc. (Esri), 2012, Geodatabase, Esri, Redlands, Calif., accessed January 27, 2012 at http://www.esri.com/software/arcgis/geodatabase/ index.html.

Garrity, C.P., and Soller, D.R., 2009, Database of the geologic map of North America-Adapted from the map by J.C. Reed, Jr. and others (2005): U.S. Geological Survey Data Series 424, http://pubs.usgs.gov/ds/424/.

Higley, D.K., compiler, 2007, Petroleum systems and assessment of undiscovered oil and gas in the Denver Basin Province, Colorado, Kansas, Nebraska, South Dakota, and Wyoming-USGS Province 39: U.S. Geological Survey Digital Data Series 69-P, http://pubs.usgs.gov/dds/dds-069/ $d d s-069-p /$.

Higley, D.K., Charpentier, R.R., Cook, T.A., Klett, T.R., Pollastro, R.M., and Schmoker, J.W., 2003, 2002 USGS Assessment of oil and gas resource potential of the Denver Basin Province of Colorado, Kansas, Nebraska, South Dakota, and Wyoming: U.S. Geological Survey Fact Sheet 002-03, 3 p., http://pubs.usgs.gov/fs/fs-002-03/.

Houseknecht, D.W., Coleman, J.L., Milici, R.C., Garrity, C.P., Rouse, W.A., Fulk, B.R., Paxton, S.T., Abbott, M.M., Mars, J.C., Cook, T.A., Schenk, C.J., Charpentier, R.R., Klett, T.R., Pollastro, R.M., and Ellis, G.S., 2010, Assessment of undiscovered natural gas resources of the Arkoma Basin Province and geologically related areas: U.S. Geological Survey Fact Sheet 2010-3043, 4 p., http://pubs.usgs.gov/ $f_{s} / 2010 / 3043 /$

IHS Energy Group, dates variable, PI/Dwights Plus U.S. Production and Well Data: Englewood, Colo., IHS Energy Group, 15 Inverness Way East, D205, Englewood, Colo. 
Kirschbaum, M.A., Condon, S.M., Finn, T.M., Johnson, R.C., Lillis, P.G., Nelson, P.H., Roberts, L.N.R., Roberts, S.B., Charpentier, R.R., Cook, Troy, Klett, T.R., Pollastro, R.M., and Schenk, C.J., 2008, Assessment of undiscovered oil and gas resources of the Bighorn Basin Province, Wyoming and Montana, 2008: U.S. Geological Survey Fact Sheet 20083050, 2 p., http://pubs.usgs.gov/fs/2008/3050/.

Kirschbaum, M.A., Anna, L., Collett, T.S., Dubiel, R.F., Finn, T.M., Hettinger, R.D., Henry, M.E., Johnson, E.A., Johnson, R.C., Lillis, P.G., Nelson, P.H., Nuccio, V.F., Rice, C.A., Roberts, L.N., and Roberts, S.B., 2002, Assessment of undiscovered oil and gas resources of the Uinta-Piceance Province of Colorado and Utah, 2002: U.S. Geological Survey Fact Sheet 157-02, 2 p., http://pubs.usgs.gov/fs/ $f_{S-157-02 \%}$

Kirschbaum, M.A., Finn, T.M., Hettinger, R.D., Johnson, E.A., Johnson, R.C., Kibler, J., Lillis, P.G., Nelson, P.H., Roberts, L.N.R., Roberts, S.B., Charpentier, R.R., Cook, T.A., Crovelli, R.A., Klett, T.R., Pollastro, R.M., and Schenk, C.J., 2002, Assessment of undiscovered oil and gas resources of the Southwestern Wyoming Province, 2002: U.S. Geological Survey Fact Sheet 145-02, 2 p., http://pubs.usgs.gov/fs/ $f_{s-145-02 \%}$

Kirschbaum, M.A., Finn, T.M., Johnson, R.C., Kibler, J., Lillis, P.G., Nelson, P.H., Roberts, L.N.R., Roberts, S.B., Charpentier, R.R., Cook, T., Klett, T.R., Pollastro, R.M., and Schenk, C.J., 2005, Assessment of undiscovered oil and gas resources of the Wind River Basin Province, 2005: U.S. Geological Survey Fact Sheet 2005-3141, 5 p., http://pubs. usgs.gov/fs/2005/3141/.

Kirschbaum, M.A., and Hettinger, R.D., 2004, Facies Analysis and sequence stratigraphic framework of Upper Campanian strata (Neslen and Mount Garfield Formations, Bluecastle Tongue of the Castlegate Sandstone, and Mancos Shale), Eastern Book Cliffs, Colorado and Utah: U.S. Geological Survey Digital Data Series 69-G, 58 p., http://pubs.usgs. gov/dds/dds-069/dds-069-g/, [Also available on CD-ROM.]

Milici, R.C., Coleman, J.L., Rowan, E.L., Cook, T.A., Charpentier, R.R., Kirschbaum, M.A., Klett, T.R., Pollastro, R.M., and Schenk, C.J., 2012, Assessment of undiscovered oil and gas resources of the East Coast Mesozoic basins of the Piedmont, Blue Ridge Thrust Belt, Atlantic Coastal Plain, and New England Provinces, 2011: U.S. Geological Survey Fact Sheet 2012-3075, 2 p., http://pubs.usgs.gov/ $f_{S} / 2012 / 3075 /$.

Milici, R.C., Ryder, R.T., Swezey, C.S., Charpentier, R.R., Cook, T.A., Crovelli, R.A., Klett, T.R., Pollastro, R.M., and Schenk, C.J., 2003, Assessment of undiscovered oil and gas resources of the Appalachian Basin Province, 2002: U.S. Geological Survey Fact Sheet 009-03, 4 p., http://pubs. usgs.gov/fs/fs-009-03/.
Milici, R.C., and Swezey C.S., 2006, Assessment of Appalachian basin oil and gas resources: Devonian shale-Middle and Upper Paleozoic Total Petroleum System: U.S. Geological Survey Open-File Report 2006-1237, http://pubs. usgs.gov/of/2006/1237/.

Nelson, P.H., and Santus, S.L., 2011, Gas, water, and oil production from Wattenberg field in the Denver Basin, Colorado: U.S. Geological Survey Open-File Report 2011-1175, 23 p., 2 pls., http://pubs.usgs.gov/of/2011/1175/.

Pawlewicz, M.J., and Finn, T.M., 2013, New vitrinite reflectance data for the Wind River Basin, Wyoming: U.S. Geological Survey Open-File Report 2013-1002, 11 p., http://pubs.usgs.gov/of/2013/1002/.

Reed, J.C., Jr., Wheeler, J.O., and Tucholke, B.E., 2005, Geologic map of North America-Perspectives and explanation: Boulder, Colo., Geological Society of America, Decade of North American Geology, 3 sheets $(74 \times 39)$, scale 1:5,000,000, 28 p., accessed June 5, 2013 at http://www.geosociety.org/news/pr/05-04.htm.

Ridgley, J.L., Anna, L.O., Condon, S.M., Fishman, N.S., Hester, T.C. Lillis, P.G., Rowan, E.L., Charpentier, R.R., Cook, T.A., Crovelli, R.A., Klett, T.R., and Schenk, C.J., 2008, Assessment of undiscovered biogenicg gas resources, northcentral Montana province: U.S. Geological Survey Fact Sheet 2008-3036, 2 p., http://pubs.usgs.gov/fs/2008/3036/.

Ridgley, J.L., Condon, S.M., Dubiel, R.F., Charpentier, R.R., Cook, T.A., Crovelli, R.A., Klett, T.R., Pollastro, R.M., and Schenk, C.J., 2002, Assessment of undiscovered oil and gas resources of the San Juan Basin Province of New Mexico and Colorado, 2002: U.S. Geological Survey Fact Sheet 147-02, http://pubs.usgs.gov/fs/fs-147-02/.

Roberts, L.N.R., Finn, T.M., Lewan, M.D., and Kirschbaum, M.A., 2008, Burial history, thermal maturity, and oil and gas generation history of source rocks in the Bighorn Basin, Wyoming and Montana: U.S. Geological Survey Scientific Investigations Report 2008-5037, 28 p., http://pubs.usgs. gov/sir/2008/5037/.

Ryder, R.T., 2008, Assessment of Appalachian basin oil and gas resources-Utica-Lower Paleozoic Total Petroleum System: U.S. Geological Survey Open-File Report 20081287, 29 p., http://pubs.usgs.gov/of/2008/1287.

Stanley, R.G., Charpentier, R.R., Cook, T.A., Houseknecht, D.W., Klett, T.R., Lewis, K.A., Lillis, P.G., Nelson, P.H., Phillips, J.D., Pollastro, R.M., Potter, C.J., Rouse, W.A., Saltus, R.W., Schenk, C.J., Shah, A.K., and Valin Z.C., 2011, Assessment of undiscovered oil and gas resources of the Cook Inlet region, south-central Alaska, 2011: U.S. Geological Survey Fact Sheet 2011-3068, 2 p., http://pubs. usgs.gov/fs/2011/3068/. 
Stanley, R.G., Pierce, B.S., and Houseknecht, D.W., 2011, U.S. Geological Survey 2011 assessment of undiscovered oil and gas resources of the Cook Inlet region, south-central Alaska: U.S. Geological Survey Open-File Report 20111237, 37 p., http://pubs.usgs.gov/of/2011/1237/.

U.S. Department of the Interior (DOI), 2008, The National Atlas of the United States of America: U.S. Department of the Interior, accessed in 2008 at http://www.nationalatlas.gov/.

U.S. Geological Survey Bighorn Basin Assessment Team, 2010, Petroleum systems and geologic assessment of oil and gas in the Bighorn Basin Province, Wyoming and Montana: U.S. Geological Survey Digital Data Series 69-V, 8 chaps., pages variable, http://pubs.usgs.gov/dds/dds-069/ $d d s-069-v /$.

U.S. Geological Survey Eastern Oregon and Washington Province Assessment Team, 2008, Geologic assessment of undiscovered gas resources of the Eastern Oregon and Washington Province: U.S. Geological Survey Digital Data Series 69-O, 5 chaps., http://pubs.usgs.gov/dds/dds-069/ $d d s-069-o /$. [Also available on CD-ROM.]

U.S. Geological Survey San Juan Basin Assessment Team, 2013, Total petroleum systems and geologic assessment of undiscovered oil and gas resources in the San Juan Basin Province, exclusive of Paleozoic rocks, New Mexico and Colorado: U.S. Geological Survey Digital Data Series 69-F, variously paged. http://pubs.usgs.gov/dds/dds-069/dds069-fl

U.S. Geological Survey Southwestern Wyoming Province Assessment Team, 2005, Petroleum systems and geologic assessment of oil and gas in the Southwestern Wyoming Province, Wyoming, Colorado, and Utah: U.S. Geological Survey Digital Data Series 69-D, http://pubs.usgs.gov/dds/ $d d s-069 / d d s-069-d /$.

U.S. Geological Survey Uinta-Piceance Province Assessment Team, 2003, Petroleum systems and geologic assessment of oil and gas the Uinta-Piceance Province, Utah and Colorado: U.S. Geological Survey Digital Data Series 69-B, http://pubs.usgs.gov/dds/dds-069/dds-069-b/.

U.S. Geological Survey Wind River Province Assessment Team, 2007, Petroleum systems and geologic assessment of oil and gas in the Wind River Province, Wyoming: U.S. Geological Survey Digital Data Series 69-J, http://pubs. usgs.gov/dds/dds-069/dds-069-j/.
Publishing support provided by:

Denver Publishing Service Center

For more information concerning this publication, contact: Center Director, USGS Central Energy Resources Science Center Box 25046, Mail Stop 939

Denver, CO 80225

(303) 236-1647

Or visit the Central Energy Resources Science Center Web site at: http://energy.usgs.gov/

This report is available at: $h t t p: / / d x . d o i . o r g / 10.3133 / d d s 69 H H$ 


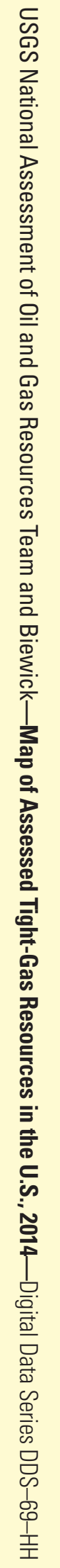

